\title{
Alleviation of terminal drought stress in wheat by foliar application of zinc and manganese
}

\author{
Keyvan Shams \\ Department of Crop Production, College of Agriculture, Kermanshah Branch, Islamic Azad University, \\ Kermanshah, Iran.
}

\begin{abstract}
In order to study the effect of drought stress and foliar application of micronutrients on agronomical properties of wheat cultivar Sirvan, the experiments were carried out at the Agricultural Research Field of Islamic Azad University of Kermanshah during the 2015-16 and 2016 -17 growing seasons. The experiments were performed in a split-plot format in a randomized complete-block design based on 4 replications. The main plots included irrigation treatments at three levels: $I_{1}$ - normal irrigation, $I_{2}$ - irrigation withdraw from the beginning of the flowering stage to the end of the growth period, and $\mathrm{I}_{3}$-irrigation withdraw from the beginning of the grain filling stage to the end of the growth period and the sub-plots included foliar application treatments at four levels: $S_{0}-$ foliar application of water, $S_{1}$ - foliar application of zinc, $S_{2}$ - foliar application of manganese and $S_{3}$ - foliar application of zinc and manganese. Significant interaction between stress levels and foliar application showed that the number of spikes per plant in treatment where irrigation withdraw at flowering and irrigation withdraw at the grain filling stage was affected by both zinc and manganese foliar application treatments and increased with irrigation water compared to foliar application treatments. The number of grains per spike followed the same trend and no significant difference was found between treatments at different levels of stress and foliar application regarding 1000 grain weight. A significant interaction between stress and foliar application levels on grain yield and harvest index showed that wheat Sirvan cultivar behavior in two years of experiment is different from that of foliar application levels at each level of stress. In general, the results of the experiments revealed that the tolerance of wheat cultivar Sirvan under terminal drought stress conditions increased with zinc and manganese foliar application and had a high yield stability.
\end{abstract}

Keywords: Drought stress, foliar application, grain yield, micronutrient, wheat

\section{Introduction}

Wheat is one of the most important cereals in the world, which has the third place in terms of production after corn and rice. About $17 \%$ of the total agricultural lands' area in the world is devoted to the cultivation of various types of wheat, and it provides food for $40 \%$ of the world's population (Asif et al., 2014). Water shortage is one of the major problems of wheat production in Iran. Since Iran's rainfall and water resources are limited, optimal water use seems to be essential. Optimal use of water volume units is one of the main goals of the policies of increasing the efficiency of water resources of the country. Under water shortage, the reproductive growth of the plant is more dependent on the leaf and stem reserves, and the lack of appropriate grain formation can be due to the lack of photosynthetic material provided during pollination, grain filling, or before it (Zinselmeier et al., 1995). For many reasons, such as calcareous matter, low organic matter, and high calcium carbonate in most of the dry and semi-arid regions of the country, there is a shortage of zinc and manganese. On the other hand, under these stress conditions, in these regions, access to nutrients, absorption and transfer of materials are disturbed (Lauer, 2003). The amount of dissolved nutrients available in the soil for root uptake and transfer of nutrients from root to stem is reduced due to lack of soil moisture that reduced transpiration, active transfer and membrane permeability. Therefore, reducing the access to nutrients is one of the most important factors of growth limitation under stress conditions (Hussein, 2009). Nutrients' foliar application has a significant effect on nutrient supply when the use of soil nutrient cannot compensate for shortage (Sarkar, 2007). Foliar application is thus necessary to compensate the shortage of nutrient intake due to root or direct nutrient shortage, as well as to quickly feed the plant. Application of zinc and manganese enhances the root system, as a result, the plant can absorb water from the depths of the soil and thus increase water use and

\footnotetext{
*Email: keyvan@iauksh.ac.ir
} 
nutrient efficiency and reduce the amount of nutrient leaching (Gadallah, 2000). Zn and Mn micronutrients can affect the plant sensitivity to drought (Khan et al., 2003). Zinc is an essential and efficient element involved in all 6 classes of enzymes in plants (oxidoreductase, transferase, lyase, isomerase, hydrolase and ligase) and therefore, it plays an important role in the synthesis of proteins and carbohydrates, metabolism of cells, protection of the membrane from oxygen free radicals and other processes associated with the plant adaptation (Hemantaranjan, 1996). Manganese is also one of the important micronutrients for the plant and is involved in the process of photosynthesis that plays an important role in the release of molecular oxygen in the process of photolysis of water, the synthesis of carbohydrate and lipid metabolism (Wilson et al., 1982) as well as a vital role in enzymatic systems that are effective on the synthesis of auxins, nitrogen metabolism, $\mathrm{CO}_{2}$ assimilation, and etc. Apparently, zinc and manganese foliar application for these elements' defect can increase wheat yield and yield components that in many experiments, the role of zinc and manganese has been mentioned in increasing the quality and quantity of wheat (Rezaul Karim et al, 2012), Alfalfa (Grewal and Williams, 2000) and maize (Muhammad and Khan, 2003). The use of three micronutrients (zinc, boron and manganese) may affect the plants' susceptibility to drought in various ways, in this regard, the active species of oxygen interact. At the first stage, zinc, boron and manganese are involved in the detoxification of oxygen active species and play a protective role in preventing photo oxidation damage by active oxygen species in the chloroplasts. At the next stage, these micronutrients may greatly contribute to drought stress through protection against oxidative damage of the membrane (Selote et al., 2004). Under drought stress conditions, the extent to which single or combined use of zinc and manganese micronutrients can reduce stress damage is not well known, hence this experiment was designed and performed with the aim of evaluating the effect of foliar application of micronutrients on wheat under drought stress conditions.

\section{Materials and Methods}

This research was conducted during the 2015-2016 and 2016-2017 growing seasons at the field of Agricultural Research of Islamic Azad University of Kermanshah, Iran $\left(34^{\circ} 20^{\prime} \mathrm{N}, 47^{\circ} 20^{\prime} \mathrm{E}\right.$; elevation $\left.1351 \mathrm{~m}\right)$. The experiments were carried out in a split-plot format based on a randomized complete-block design in 4 replications. The main plots included irrigation treatments at three levels: $I_{1}$ normal irrigation (irrigation at all stages of plant growth), $\mathrm{I}_{2}$ - irrigation withdraw from the beginning of the flowering stage to the end of the growth period and $\mathrm{I}_{3}$ - irrigation withdraw from the beginning of grain filling stage to the end of the growth period. The 4 foliar application levels of $\mathrm{S}_{0}$ (foliar application of water (control)), $\mathrm{S}_{1}$ (zinc foliar application), $S_{2}$ (manganese foliar application), and $S_{3}$ (zinc and manganese foliar application) were treated using the allocated sub-plots. Wheat cultivar Sirvan was obtained from Cereal Research Department, Seed and Plant of Improvement Institute, Karaj, Iran. The soil of the experiment site had a clay loamy texture with a $\mathrm{pH}$ of 6.4 and an electrical conductivity of $0.56 \mathrm{dSm}^{-1}$. According to the results of soil analysis, organic matter content was $0.72 \%$, phosphorus, potassium, zinc and manganese were $8.5,178,0.82$ and $6.5 \mathrm{mgkg}^{-1}$, respectively. The total nitrogen content was $0.19 \%$. One hundred kilograms per hectare of potassium (from the source of potassium sulfate) and $100 \mathrm{~kg} \mathrm{ha}^{-1}$ of pure phosphorus (from triple super phosphate source) were used as baseline. The amount of used nitrogen fertilizer was also $150 \mathrm{~kg} \mathrm{ha}^{-1}$ from the source of urea, which was applied to the soil at three stages: $1 / 3$ before planting, $1 / 3$ at tillering stage and $1 / 3$ at stemming stage. Foliar application was applied at the end of the tillering stage and the early stage of stemming of wheat at a concentration of 5-1000 and was repeated once every 2 weeks. Land preparation operations include once plowing with a moldboard plow and twice plowing using disk and leveler. The grains were planted in November. Each plot consists of 6 planting lines with a length of $5 \mathrm{~m}$ and a spacing of $20 \mathrm{~cm}$. Sub-plots were spaced apart from each other with a planting line $(20 \mathrm{~cm})$, the main plots' spacing from each other was 5 planting lines $(1 \mathrm{~m})$, and the distance between the replications was $4 \mathrm{~m}$. Four hundred seeds per square meter were considered for the wheat density. Before planting, the seeds were disinfected with Mancozeb fungicide. After planting, the seeds were irrigated based on the predicted treatments. Broad leaf weeds were controlled using 2, 4-D herbicide and narrow leaf weeds were manually controlled. At the time of harvesting, the plants of lines 2 and 3 were harvested after removing $0.5 \mathrm{~m}$ from each side of each plot. First, the spikes were separated from the rest of the plant parts and then, 10 spikes were randomly selected among the isolated spikes to determine the yield components, and the remaining spikes were weighed after counting and then threshed. The obtained grains were weighed with accurate weighing scale and grain yield was obtained. The traits such as the plant height, number of grains per spike, 1000 grain weight, and spikes per unit area were determined using 10 selected spikes. Finally, by weighing 4 samples of $n=500$ of each treatment, 1000 grain weight was determined. The height of the plant $(\mathrm{n}=$ 10) was obtained by measuring the surface of the soil to the tip of the spike, regardless of the awn. The number of spikes per unit area was calculated by counting the number of 
spikes that can be harvested. The biological yield was obtained from the total weighing of harvested plants in lines 2 and 3, and harvest index was obtained from the ration of the grain yield to biological yield $x 100$. The analysis of the combined variance of the data was based on the experiment of split plots and a completely randomized block design in two years. It should be noted that Bartlett test was used to evaluate the uniformity of experimental errors' variance, and the results of chi-square showed the uniformity of experimental errors' variance in two years. Statistical analysis was performed using MSTATC and SPSS software and mean comparison was done using Duncan's method at 5\% probability level. Simple correlation analysis between traits and significance was done by Pearson's method. Charts were plotted using Excel software.

\section{Results and Discussion}

Table 1 shows the combined analysis of variance and mean comparison of simple effects of stress and foliar application on agronomical and biochemical properties of wheat. Figure 1a shows the mean comparison of harvest index that in normal irrigation treatment $\left(\mathrm{I}_{1}\right)$, foliar application levels (S) have a significant difference with each other, so that foliar application increased harvest index and the highest harvest index compared to foliar application with water $\left(S_{0}\right)$ is related to zinc foliar application $\left(S_{1}\right)$, although it is not significantly different from manganese $\left(\mathrm{S}_{2}\right)$ and zinc and manganese $\left(\mathrm{S}_{3}\right)$ foliar application, zinc foliar application treatment $\left(S_{1}\right)$ compared to foliar application treatment with water $\left(\mathrm{S}_{0}\right)$ has increased harvest index by about 9\%. In irrigation withdraw from the beginning of flowering stage to the end of growth period $\left(\mathrm{I}_{2}\right)$, the levels of foliar application (S) were significantly different from each other, so that in this treatment, also foliar application increased the harvest index and the highest harvest index compared to irrigation foliar application with water $\left(\mathrm{S}_{0}\right)$ is due to zinc $\left(\mathrm{S}_{1}\right)$ foliar application, which is not significantly different from manganese $\left(\mathrm{S}_{2}\right)$, and $\mathrm{Zn}$ and manganese $\left(\mathrm{S}_{3}\right)$ foliar application. Zinc (S1) foliar application compared to foliar application treatment with water $\left(\mathrm{S}_{0}\right)$ has increased harvest index by about $7 \%$ (Figure 1a). Irrigation withdraw treatment from the grain filling stage to the end of the growth period $\left(\mathrm{I}_{3}\right)$ showed a significant difference between the levels of foliar application (S), so that the highest harvest index compared to foliar application with irrigation water $\left(\mathrm{S}_{0}\right)$ was related to

Table 1: Effect of foliar application and drought stress on agronomical characteristics in wheat (data derived mean two years).

\begin{tabular}{|c|c|c|c|c|c|c|c|}
\hline Treatment & $\mathrm{PH}$ & NSPP & NGPS & TGW & GY & BY & $\mathrm{HI}$ \\
\hline \multicolumn{8}{|c|}{ Drought stress } \\
\hline I1 & $85 a$ & $3.51 \mathrm{a}$ & $36.15 \mathrm{a}$ & $39.35 \mathrm{a}$ & $7754 a$ & $18823 a$ & $42.19 \mathrm{a}$ \\
\hline I2 & $73 \mathrm{c}$ & $3.33 \mathrm{c}$ & $28.90 \mathrm{c}$ & $33.17 \mathrm{c}$ & $6813 c$ & $16029 \mathrm{c}$ & $36.15 \mathrm{c}$ \\
\hline I3 & $82 \mathrm{~b}$ & $3.39 \mathrm{~b}$ & $33.65 \mathrm{~b}$ & $37.77 \mathrm{~b}$ & $7479 b$ & $16199 \mathrm{~b}$ & $38.77 \mathrm{~b}$ \\
\hline \multicolumn{8}{|c|}{ Foliar application } \\
\hline So & $81.19 b$ & $3.09 \mathrm{~d}$ & $32.19 \mathrm{~d}$ & $39.38 \mathrm{a}$ & $6874 d$ & $18129 \mathrm{a}$ & $36.29 \mathrm{~b}$ \\
\hline S1 & $85.14 a$ & $3.39 \mathrm{~b}$ & $33.27 \mathrm{c}$ & $39.18 \mathrm{a}$ & $7593 a$ & $17459 a$ & $38.55 \mathrm{a}$ \\
\hline S2 & $85.47 \mathrm{a}$ & $3.33 \mathrm{c}$ & $34.17 b$ & $39.87 \mathrm{a}$ & $7358 b$ & $17899 \mathrm{a}$ & $38.81 \mathrm{a}$ \\
\hline S3 & $85.59 \mathrm{a}$ & $3.48 \mathrm{a}$ & $36.75 \mathrm{a}$ & $39.98 \mathrm{a}$ & $7135 c$ & $17986 a$ & $38.57 \mathrm{a}$ \\
\hline \multicolumn{8}{|c|}{ Year } \\
\hline First year & $81.55 \mathrm{a}$ & $3.65 \mathrm{a}$ & $35.67 a$ & $39.46 \mathrm{a}$ & $8556 a$ & 18981a & $41.22 \mathrm{a}$ \\
\hline Second year & $73.82 \mathrm{~b}$ & $3.14 \mathrm{~b}$ & $30.34 \mathrm{~b}$ & $36.43 \mathrm{a}$ & $7979 b$ & $17658 b$ & $37.64 \mathrm{~b}$ \\
\hline Drought stress(D) & $* *$ & $* *$ & $* *$ & $* *$ & $* *$ & ** & ** \\
\hline Foliar application $(F)$ & ** & *** & *** & ns & ** & ns & ** \\
\hline $\mathrm{D} \times \mathrm{F}$ & * & * & * & ns & ** & ns & ** \\
\hline Year & $*$ & ns & $* *$ & ns & $*$ & ns & $* *$ \\
\hline $\mathrm{CV} \%$ & 7.54 & 12.16 & 8.41 & 11.36 & 10.45 & 12.63 & 14.68 \\
\hline
\end{tabular}

Note: PH-Plant height, NSPP-Number of spikes per plant, NGPS-Number of grains per spikes, TGW-Thousand grain weight, GYGrain yield, BY-Biological yield, HI-Harvest index. Within treatment means followed by the same letter are not significant at $p<0.05$ according to Duncan's multiple range test. ${ }^{*} p<0.05,{ }^{* *} p<0.01,{ }^{n s}-$ Non-signification. 
zinc foliar application $\left(\mathrm{S}_{1}\right)$, which is not significantly different from manganese $\left(S_{2}\right)$ and $\mathrm{Zn}$ and $\mathrm{Mn}$ foliar application $\left(S_{3}\right)$. Zinc $\left(S_{1}\right)$, manganese $\left(S_{2}\right)$, and $Z n$ and $M n$ $\left(\mathrm{S}_{3}\right)$ foliar application treatments increased harvest index by 10,8 and $6 \%$, respectively, compared to foliar application with irrigation water $\left(\mathrm{S}_{0}\right)$ (Fig. 1a). Table 1 shows the mean comparison of drought stress levels in relation to agronomical and biochemical properties of wheat. Harvest index has been affected by drought stress treatment during flowering and grain filling stages, with the highest harvest index in normal irrigation treatment $\left(\mathrm{I}_{1}\right)$ and the lowest observed in drought stress treatment at flowering stage $\left(\mathrm{I}_{2}\right)$. Drought stress applied at flowering stage $\left(\mathrm{I}_{2}\right)$ and grain filling (I3) reduced biological yield and grain yield with the same ratio, which reduced the harvest index as compared to no stress $\left(\mathrm{I}_{1}\right)$ treatment. This may be due to water constraint that both biological yield and grain yield reduced, biological yield under stress conditions is less than the reduction in grain yield. In fact, by reducing the number of irrigations rounds due to the sharp reduction in grain yield, the harvest index also reduced (Patra et al., 1999). In this regard, the results of most studies have confirmed the results of this study. In this regard, Gupta et al. (2001) reported that the number of grains, grain yield, biological yield, harvest index and dry weight of the shoot reduced by applying drought stress at pollination stage. Also, drought stress at flowering stage has a greater effect on grain yield. In the study of three wheat cultivars at the stages of tailoring, node formation, spike formation in leaf sheath and flowering stage under drought stress, it was observed that although wheat grain yield reduced significantly at all stages of growth, the maximum yield reduction was obtained from the application of drought stress at the flowering stage, all drought stress treatments significantly reduced harvest index (Jamal et al., 1996). Table 1 presents the mean comparison of foliar application levels with respect to agronomical and biochemical properties of wheat so that also, zinc $\left(S_{1}\right)$ foliar application significantly increased harvest index compared to foliar application treatment with water $\left(\mathrm{S}_{0}\right)$, but no significant difference was observed between zinc $\left(\mathrm{S}_{1}\right)$, which was not significantly different with manganese $\left(S_{2}\right)$ and zinc and manganese $\left(\mathrm{S}_{3}\right)$ foliar application treatments, which seems to be due to the allocation of a larger amount of matter to grain compared to vegetative organs, due to the application of foliar application of micronutrients, in other words, the use of micronutrients for better utilization of starch content and the better allocation in the grain and the transfer of assimilates to the developing grain which increases the size and number of grains in the spike, leads to an increase in the harvest index. In fact, micronutrient foliar application at the stages of vegetative and reproductive growth in wheat, due to its effect on physiological and biochemical processes, leads to more dry matter production (Torun et al., 2001). Fig. 1b shows the mean comparison of grain yield that normal irrigation $\left(\mathrm{I}_{1}\right)$ treatment with zinc foliar application $\left(S_{1}\right)$ had higher grain yield than foliar application with water $\left(\mathrm{S}_{0}\right)$, but no significant difference was observed between $\mathrm{Mn}\left(\mathrm{S}_{2}\right)$, and $\mathrm{Zn}$ and $\mathrm{Mn}\left(\mathrm{S}_{3}\right)$ foliar application treatments. On the one hand, no significant difference was observed between $\mathrm{Zn}\left(\mathrm{S}_{1}\right)$ and $\mathrm{Mn}\left(\mathrm{S}_{2}\right)$ foliar application treatments, but a significant difference was observed between $\left(S_{1}\right)$ and $\left(S_{3}\right)$, so that in zinc $\left(S_{1}\right)$, manganese $\left(S_{2}\right)$, and zinc and manganese $\left(S_{3}\right)$ foliar application treatments, grain yield increased by 520,283 , and $211 \mathrm{~kg} \mathrm{ha}^{-1}$, respectively compared to $\mathrm{S}_{0}$ foliar application. In irrigation withdraw treatment $\left(\mathrm{I}_{2}\right)$, zinc $\left(\mathrm{S}_{1}\right)$ foliar application produced more yield than that of foliar application with water $\left(\mathrm{S}_{0}\right)$, which showed a significant difference between $\left(S_{1}\right)$ and $\left(S_{3}\right)$ foliar application treatments, so that zinc foliar application $\left(S_{1}\right)$ increased grain yield by about $325 \mathrm{~kg} \mathrm{ha}^{-1}$ compared to foliar application with water $\left(\mathrm{S}_{0}\right)$ (Fig. 1b). In irrigation withdraw treatment $\left(I_{3}\right)$, foliar application treatment $\left(S_{1}\right)$ had higher yield than foliar application treatment $\left(S_{0}\right)$ and no significant difference was observed between $\left(\mathrm{S}_{2}\right)$ and $\left(\mathrm{S}_{3}\right)$ foliar application treatments. Foliar application treatment $\left(\mathrm{S}_{1}\right)$ increased grain yield by about $719 \mathrm{~kg} \mathrm{ha}^{-1}$ compared to foliar application treatment $\left(\mathrm{S}_{0}\right)$ (Fig. 1b). In this regard, researchers reported that the use of micronutrients as foliar application, in addition to increasing the quantitative yield, also had an effect on the improvement of forage quality in millet, which could be associated with increased drought stress tolerance (Cramer and Nowarc, 1992). Grewal and Williams (2000) reported that adequate nutrition is essential for both drought tolerance and waterlogged stress and leads to increased yield in alfalfa. In this study, it was found that the most sensitive growth stage of wheat is flowering stage and mean grain yield is $7250 \mathrm{~kg} \mathrm{ha}^{-1}$ in Sirvan cultivar. A significant difference was observed between foliar application treatment $\left(S_{1}\right)$ and treatment $\left(S_{0}\right)$ in relation to grain yield, with an increase in yield by $700 \mathrm{~kg} \mathrm{ha}^{-1}$ and foliar application treatments $\left(S_{2}\right)$ and $\left(S_{3}\right)$ are after $\left(S_{1}\right)$ (Table 1). In fact, micronutrients ( $\mathrm{Zn}, \mathrm{Fe}$, and $\mathrm{B}$ ) when used separately or in combination, significantly improved wheat yield compared to the control (Chaudry et al., 2007). The increase in wheat yield has been reported with the use of iron, manganese, zinc and copper by 780, 540, 860, and 480 $\mathrm{kg} \mathrm{ha}{ }^{-1}$, respectively, (Tandon, 1995). In this regard, Cakmak et al. (1996) have reported that zinc in wheat cultivars increased wheat yield from $5-54 \%$. In general, numerous studies have shown that low foliar application, especially zinc, boron and manganese, can increase the yield of products (Kutman et al., 2010). In fact, the effect of micronutrients on grain yield can be justified as follows that 
these elements increase grain yield and biological yield by increasing the amount of photosynthesis and improving the durability of leaf area. Regarding biological yield, no significant difference was observed between treatments at different levels of foliar application (Table 1). Table 1 shows the mean comparison of drought stress levels in relation to agronomical and biochemical properties of wheat so that no significant difference was observed between treatments of irrigation withdraw at flowering stage $\left(\mathrm{I}_{2}\right)$ and irrigation withdraw at grain filling stage $\left(I_{3}\right)$ compared to
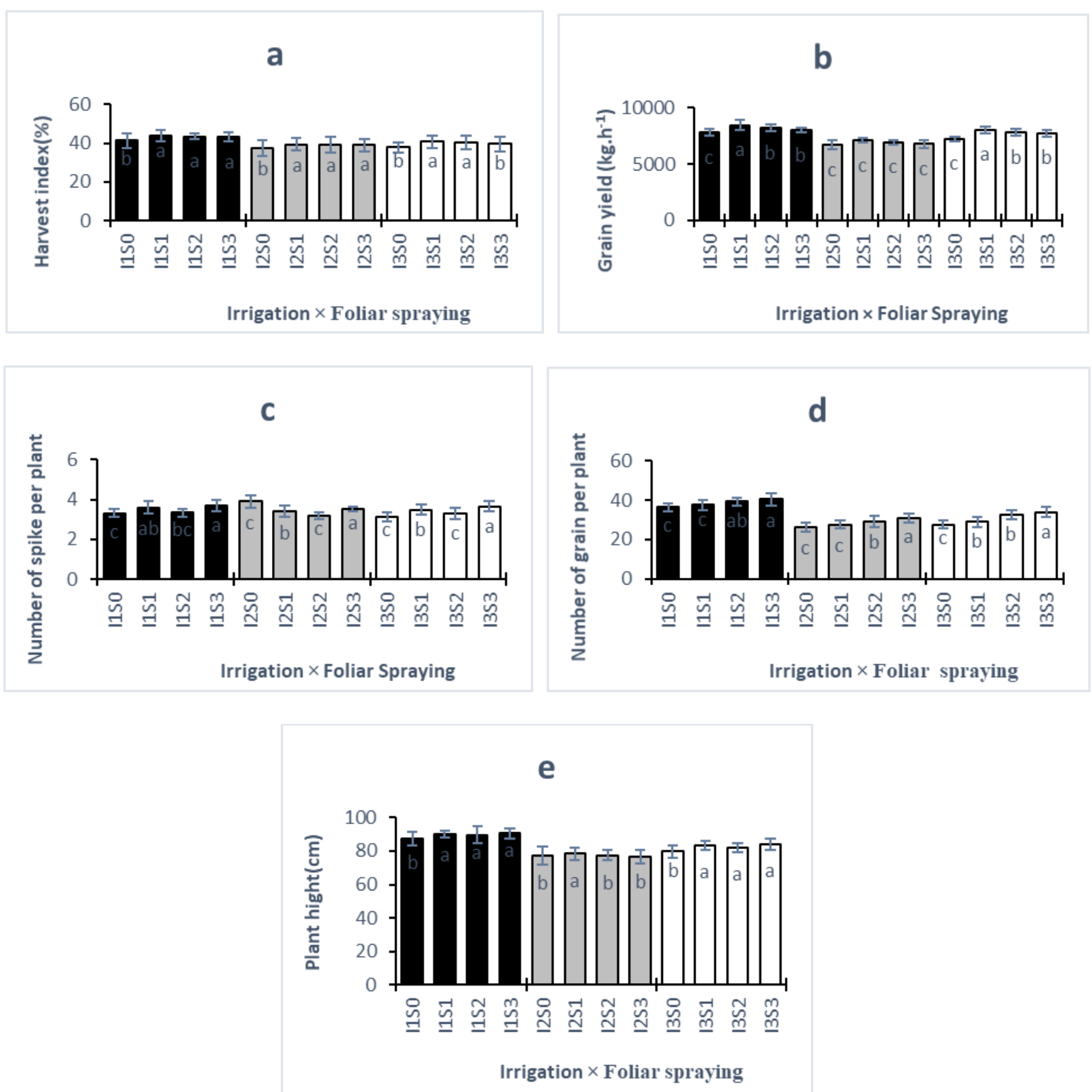

Figure 1: Effect of irrigation and foliar application on, a -Harvest index, $b$-Grain yield, c-Number of spikes per plant d - Number of grains per spike e -Plant height.

Note: $\mathrm{I}_{1}$ - normal irrigation, $\mathrm{I}_{2}$ - irrigation withdraw from the beginning of the flowering stage to the end of the growth period, and $\mathrm{I}_{3}-$ irrigation withdraw from the beginning of the grain filling stage to the end of the growth period and $\mathrm{S}_{0}$ - foliar application with water, $S_{1}$ - foliar application with zinc, $S_{2}$ - foliar application with $M n$ and $S_{3}$ - foliar application with zinc and manganese. Within treatment means followed by the same letter are not significantly at $p<0.05$ according to Duncan's multiple range test. 
normal irrigation $\left(\mathrm{I}_{1}\right)$ on grain yield and biological yield, so that the greatest reduction in grain yield and biological function was observed in irrigation withdraw treatment $\left(I_{2}\right)$. In fact, damages due to drought stress were great at flowering stage because the occurrence of drought stress during pollination and inoculation induces floral sterility (Bradford, 1994) and reduces the total number of grains produced per single spike, resulting in reduced yield. And if drought stress occurs during grain filling, remobilization of the matter to the grain will have a critical effect on grain yield (Ehdaie and Waines, 1996). Fig. 1c, d and e show the interaction between two factors of stress and foliar application on the number of spikes per plant, number of grains per spike and plant height. The number of spikes per plant at stress levels $\left(I_{1}, I_{2}\right.$ and $\left.I_{3}\right)$ was influenced by zinc and manganese $\left(\mathrm{S}_{3}\right)$ foliar application and increased compared to foliar application with water $\left(\mathrm{S}_{0}\right)$ (Fig. 1c). The number of grains per spike follows the same trend (Fig. 1d). No significant difference was observed between treatments at different levels of stress and foliar application in 1000 grain weight (Table 1). The plant height was affected by foliar application in stress treatment $\left(\mathrm{I}_{1}\right)$ a significant difference was observed between the levels of foliar application $\left(\mathrm{S}_{1}\right)$, $\left(\mathrm{S}_{2}\right)$ and $\left(\mathrm{S}_{3}\right)$ relative to $\left(\mathrm{S}_{0}\right)$, although no significant difference was observed between $\left(\mathrm{S}_{1}\right)$ and $\left(\mathrm{S}_{2}\right)$ and $\left(\mathrm{S}_{3}\right)$ foliar application, zinc and manganese $\left(S_{3}\right)$ foliar application increased the height by about $6 \%$ compared to foliar application with water $\left(\mathrm{S}_{0}\right)$ (Figure 1e). The plant height in stress treatment $\left(\mathrm{I}_{2}\right)$ was also influenced by foliar application, so that $\mathrm{Zn}$ foliar application $\left(\mathrm{S}_{1}\right)$ shows the highest height compared to other foliar application levels (Figure 1e). The plant height in stress treatment $\left(I_{3}\right)$ has also been affected by the foliar application levels and its trend is similar to stress $\left(\mathrm{I}_{1}\right)$ at different levels of foliar application, although no significant difference was observed between the levels of foliar application $\left(S_{1}\right),\left(S_{2}\right)$ and $\left(S_{3}\right)$ in terms of the height, the highest height is observed in zinc and manganese $\left(\mathrm{S}_{3}\right)$ foliar application (Fig. 1e). Table 1 indicates the mean comparison of drought stress levels in relation to agronomical and biochemical properties of wheat, so that the highest number of spikes per plant, number of grains per spike, 1000 grain weight and height was related to stress treatment $\left(\mathrm{I}_{1}\right)$ and the lowest was related to stress treatment $\left(\mathrm{I}_{2}\right)$. In fact, applying stress at the flowering stage would disrupt the current photosynthesis and transfer the storing matter to the grain. This can be due to the reduction in the number and weight of grain (Richardes et al., 2001). In other words, water constraint during the reproductive stages through the disturbance in pollination and reducing the length of the period reduced the number of grains per spike (Patra et al., 1999). Environmental stresses between stages 21 (tillering) and 65 (flowering) had the greatest effect on the number of grains, dry matter production of shoot, harvest index, grain protein yield, number of spikes per square meter, number of grains per spike and grains per square meter (Entz and Fowler, 1988). Application of drought stress, independent of the occurrence of stress reduced the grain yield of wheat. Table 1 presents the mean comparison of the levels of foliar application with respect to agronomical and biochemical properties of wheat, so that in relation to the number of spikes per plant, a significant difference was observed between the levels of foliar application that the level of foliar application of zinc and manganese $\left(\mathrm{S}_{3}\right)$ had the highest number of spikes per plant compared to the level of foliar application with irrigation water level $\left(\mathrm{S}_{0}\right)$ and the levels of zinc $\left(\mathrm{S}_{1}\right)$ and manganese $\left(S_{2}\right)$ foliar application are the next. In relation to the number of grains per spike, we observed a similar trend to the number of spikes per plant. In relation to 1000 grain weight, however, no significant difference was observed between foliar application treatments, but the highest 1000 grain weight was observed in foliar application treatment $\left(\mathrm{S}_{3}\right)$ (Table 1). Hemantaranjan and Garg (1988) reported that micronutrient application in wheat significantly increased grain yield, 1000 grain weight, number of grains per spike, spike length and number of spikes per unit area. On the other hand, zinc, boron and manganese foliar application can also increase photosynthesis, pollen survival, number of fertile tillers and number of grains per wheat spike (Rezaul Karind et al., 2012). The plant height was also affected by foliar application, but no significant difference was observed between foliar application levels $\left(S_{1}, S_{2}\right.$ and $\left.S_{3}\right)$ in this regard, although numerically, foliar application level $\left(S_{3}\right)$ had the highest height, and foliar application levels $\left(S_{1}\right.$, $\mathrm{S}_{2}$ and $\mathrm{S}_{3}$ ) were significantly different from foliar application $\left(\mathrm{S}_{0}\right)$ (Table 1). An increase in the plant height with micronutrient foliar application is due to the involvement of micronutrient in various physiological processes, such as enzyme activation (Sillanpa, 1982), electron transfer (Oosterhuits and Weir, 2010), chlorophyll formation (Habib, 2009) and stomata regulation and etc. that finally lead to more dry matter production (Khan et al., 2010). Table 2 shows the mean comparison of the effect of year with respect to agronomical and biochemical properties of wheat, so that the mean grain yield in the first year $\left(\mathrm{Y}_{1}\right)$ in all experimental treatments is more than that of the second year $\left(\mathrm{Y}_{2}\right)$, which is probably due to more proper climatic conditions of the region in the first year than in the second year. On the other hand, in the second year, the mean temperature in the last months of the growth of wheat was higher, which reduced the reproductive period and thus yield of wheat (Table 2). Higher yield in the first year than in the second year has been related to harvest index, biological yield, number of spikes per plant, and number of 
grains per spike. Single or combined zinc and manganese foliar application improved yield components regardless of the interactions between stress and foliar application. In this study, significant interactions between the two factors of drought stress and foliar application on grain yield and harvest index show that wheat Sirvan cultivar in two years of experiment differs for different levels of foliar application at each stress level. For grain yield and harvest index, it was observed that wheat Sirvan cultivar was able to react positively to single and combined zinc and manganese foliar application at each stress level, so that the solution partially compensated for drought stress damage in the plant. The stress at flowering stage due to a sharp reduction in the number and weight of grains results in a sharp reduction in grain yield because the number of photosynthetic matter storing cells in the grain was determined shortly after fertilization and then it started to fill, for this reason, stress at flowering stage by reducing the number of storing cells, reduced the grain capacity to absorb the storing matter. At grain filling stage, stress due to the constraint of water or reducing storing matter and share of current photosynthesis of leaves in grain filling affected 1000 grain weight, and finally yield. The number of grains per spike and number of spikes per plant are the most important functional components that have been improved at drought stress levels with zinc or manganese or the combination of zinc and manganese. One thousand grain weight increased with zinc, manganese and zinc and manganese in comparison with foliar application treatment with irrigation water. All of these cases indicate that zinc, manganese and their combination foliar application are likely to affect photosynthesis and enzymes in metabolic pathways of turning photosynthetic matter into energy and grain storing compounds positively and increase the plant efficiency. A positive and significant correlation between yield and other traits studied under the conditions of this

Table 2: Meteorological condition in 2015 -2017

\begin{tabular}{|c|c|c|c|c|}
\hline & \multicolumn{2}{|c|}{ 2015-2016 } & \multicolumn{2}{|l|}{$2016-2017$} \\
\hline & Air temperature ${ }^{\circ} \mathrm{C}$ & Precipitation mm & Air temperature ${ }^{\circ} \mathrm{C}$ & Precipitation $\mathrm{mm}$ \\
\hline & \multicolumn{4}{|c|}{---------Monthly Mean ------------ } \\
\hline October & 19.2 & 175 & 19.3 & 0.9 \\
\hline November & 9.8 & 75.3 & 11 & 0 \\
\hline December & 3.9 & 63.8 & 6.3 & 91.2 \\
\hline January & 4.6 & 74.8 & 3.3 & 58.4 \\
\hline February & 7.7 & 65.8 & 3 & 34.9 \\
\hline March & 10.3 & 96.6 & 9.1 & 141.9 \\
\hline April & 13.9 & 155.3 & 15.9 & 108.4 \\
\hline May & 17.8 & 18.2 & 21.9 & 28.6 \\
\hline June & 25.3 & 0.2 & 27.9 & 0 \\
\hline July & 31.3 & 0 & 32.1 & 0 \\
\hline August & 31.8 & 0 & 31.7 & 0 \\
\hline September & 25 & 0 & 27.4 & 0 \\
\hline
\end{tabular}

Table 3. Coefficients of correlation between agronomical traits in wheat (data derived mean two years)

\begin{tabular}{cccccccc}
\hline Treatments & PH & NGPS & TGW & NSPP & BY & GY & HI \\
\hline PH & 1 & & & & & & \\
NGPS & 0.455 & 1 & & & & & \\
TGW & $0.166^{*}$ & $0.443^{* *}$ & 1 & & & & \\
NSPP & $0.245^{* *}$ & $0.550^{*}$ & $0.420^{* *}$ & 1 & & & \\
BY & $0.404^{*}$ & $0.500^{* *}$ & $0.333^{* *}$ & $0.445^{*}$ & 1 & & \\
GY & $0.901^{* *}$ & $0.509^{* *}$ & $0.545^{* *}$ & $0.552^{* *}$ & $0.907^{* *}$ & 1 & \\
HI & $0.545^{* *}$ & $0.950^{* *}$ & $0.663^{*}$ & $0.885^{* *}$ & $0.355^{*}$ & $0.559^{*}$ & 1 \\
\hline
\end{tabular}

Note: PH - Plant height, NSPP- Number of spikes per plant, NGPS - Number of grains per spike, TGW - Thousand grain weight, GY Grain yield, BY - Biological yield, HI - Harvest index. ${ }^{*}-p<0.05,{ }^{* *}-p<0.01$. 
study shows that in general, single and combined foliar application of zinc and manganese, if properly applied with optimal amount, would have a significant effect on the plant drought resistance. With regard to the improvement of alfalfa drought resistance, some reports have been published (Grewal and Williams, 2000). In fact, wheat cultivar Sirvan, which is resistant to terminal drought, has a positive response to zinc, manganese, and zinc and manganese foliar application under terminal drought stress conditions. In relation to the years of experiment, it seems that higher temperatures in the second year, especially after March are factors that have reduced wheat yield with increasing maintenance respiration. Increased maintenance respiration or temperature of more than $20{ }^{\circ} \mathrm{C}$ has been emphasized in other studies (Gifford, 1995; Ryan, 1991); on the other hand, high temperatures, especially at post-flowering stages, reduced grain' filling time (Evans and Fischer, 1999). Due to higher temperatures in the second year that exacerbated drought stress, followed by an increase in the amount of proline and soluble carbohydrates, although the effects of drought stress on yield were somewhat higher, especially, the cultivar Sirvan resistant to terminal drought has been modulated through micronutrient foliar application, but always the effect of drought stress on the reduction of grain yield is evident (Table 2). Table 3 shows a correlation between agronomical traits of wheat. As shown, grain yield had a positive and significant correlation with all traits, and the highest correlation was observed between grain yield and number of grains per spike (950**) and the number of spikes per plant $(663 * *)$ and 1000 grain weight $\left(545^{* *}\right)$, which shows that the most effective factors on grain yield are these three functional components, which by increasing each component, grain yield increased. A positive and significant correlation was also observed between the harvest index and the number of grains per plant $\left(509^{* *}\right)$, number of spikes per plant $\left(885^{* *}\right), 1000$ grain weight $\left(546^{* *}\right)$, plant height $(901 * *)$, and grain yield $(907 * *)$.

\section{Conclusion}

In general, the results of two-year experiments showed that Sirvan cultivar under the conditions of terminal drought stress has been able to maintain its high yield and with foliar application (zinc and manganese), its tolerance to drought also increased and has a high yield stability. It was also found that even the flowering and filling of wheat grain in the studied areas occurred from mid-May to the end of June, micronutrients' foliar application (zinc and manganese) and irrigation withdraw may result in compensation for drought stress damage to a certain extent, and with optimal use of the excess water of wheat fields in the region's cultivation pattern, the efficiency increased.

\section{Acknowledgment}

This work was supported by grant from Research Council of Islamic Azad University Kermanshah Branch Iran

\section{References}

Asif, M., M. Iqbal, H. Randhawa and D. Spaner. 2014. Managing and Breeding Wheat for Organic Systems. Springer, $82 \mathrm{p}$.

Bradford, K.J. 1994. Water stress and the water relations of seed development: A critical review. Crop Science 1: 11-58.

Cakmak, I., A. Yilmaz, M. Kalayci, H. Ekiz, B. Erenoglu and H.J. Brown. 1996. Zinc deficiency as a critical problem in wheat production in central Antonia. Plant and Soil 180:156-172.

Chaudry, E.H., V. Timmer, A.S. Javed and M.T. Siddique. 2007. Wheat response to micronutrients in rainfed areas of Punjab. Soil \& Environment 26:97-101.

Cramer, G.R. and R.S. Nowarc. 1992. Supplemental manganese improves the relative growth, net assimilation and photosynthetic rates of salt-stressed barley. Physiologya Plantarum 84:600-605.

Ehdaie, B. and J.G. Waines. 1996. Genetice variation for contribution of pre-anthesis assimiliates to grain yield in spring wheat. Journal of Genetics and Breeding 50(1):47-55.

Entz, M.H. and D.B. Fowler. 1988. Critical stress periods affecting productivity of No-till winter wheat in Western Canada. Agronomy Journal 80: 987-992.

Evans, L.T. and R.A. Fischer .1999. Yield potential: its definition, measurement and significance. Crop Science 39: 345-353.

Gadallah, N.A.A. 2000. Effects of indol -3-acetic acid and zinc on the growth, osmotic potential and soluble carbon and nitrogen components of soybean plants growing under water stress. Journal of Arid Environments 44: 451-467.

Gifford, R.M. 1995. Whole plant respiration and photosynthesis of wheat under increased $\mathrm{CO}_{2}$ concentration and temperature: longterm vs. short-term distinctions for modeling. Global Change Biology 1: 385-396.

Grewal, H.S. and R. Williams. 2000. Zinc nutrition affects alfalfa response to water stress and excessive moisture. Journal of Plant Nutrition 23:942-962.

Habib, M. 2009. Effect of foliar application of $\mathrm{Zn}$ and Fe on wheat yield and quality. African Journal of Biotechnology 8: 6795-6798. 
Hemantaranjan, A. 1996. Physiology and biochemical significance of zinc in plants. p.151-178. In: Advancement in Micronutrient Research. A. Hemantaranjan (ed.). Scientific publishers, Joudhpur Rajasthan India.

Hemantaranjan, A. and O.K. Garg. 1988. Iron and zinc fertilization with reference to the grain quality Triticum aestivum L. Journal of Plant Nutrition 11:1439-1450.

Hussein, M.M., A.A. Abd El-Kader and A.M. Mona. 2009. Mineral Status of Plant Shoots and Grains of Barley under Foliar Fertilization and Water Stress. Journal of Agriculture and Biological Sciences 5(2): 108-115.

Jamal, M., M.S. Nazir, S.H. Shah and N. Ahmed. 1996. Varietal response of wheat to water stress at different growth stages.111. Effect on grain yield, harvest index and protein content in grain. Rachis (ICARDA). Barley and Wheat Newsletter15:38-45.

Khan, H.R., G.K. McDonald and Z. Rengel. 2003. Zn fertilization improves water use efficiency, grain yield and seed Zn content in chickpea. Plant Soil 249: 389400.

Khan, M.B., M. Farooq, M.H. Shanavaz and G. Shabir 2010. Foliar Application of micronutrients improves the wheat yield and net economic return. International Journal of Agriculture and Biology 12:953-956.

Kutman, U.B., B. Yildiz, L. Ozturk and I. Cakmak. 2010. Biofortification of durum wheat with zinc through soil and foliar applications of nitrogen. Cereal Chemistry 87:1-9.

Lauer, J. 2003. What happens within the corn plant when drought occurs? Corn Agronomist 10(22): 153-155.

Muhammad, A. and A. Khan. 2003. Effect of Hall tonic fertilizer on irrigated wheat yield. Journal of Agronomy 2:28-33.

Oosterhuits, D.M. and B.L. Wier. 2010. Foliar fertilization of cotton. p.225-237. In: Physiology of Cotton. J. McD and Stewart. (eds.). Springer Science + Business Media B.V. California, USA.

Patra, D.D., M. Anwar, S. Singh, A. Prasad and D.V. Singh. 1999. Aromatic and medicinal plants for salt and moisture stress condition. Recent Advances in management of arid ecosystem. Proceeding of Symposium held in Indian, March 1997. p. 347-350.

Gupta, N. K., S. Gupta and A. Kumar. 2001. Effect of water stress on physiological attribute and their relationship with growth and yield of wheat cultivars and different stages. Agronomy Journal and Crop Science 116:55-62.
Rezaul Karim, M.D., Y.Q. Zhang, R.R. Zhao, X.P. Chen, F.S. Zhang and C.Q. Zou.2012. Alleviation of drought stress in winter wheat by late foliar application of zinc, boron, and manganese. Journal of Plant Nutrition and Soil Science 175:142-151.

Richardes, R.A., A.G. Condon and G.L. Rebetzke. 2001. Traits to improve yield in dry environment. p.88-100. In: Application of Physiology in Wheat Breeding. M.P. Reynolds, J.I. Ortiz-Monasterio and A. McNab (eds.). CIMMYT, Mexico.

Ryan, G.R. 1991. Effects of climate change on plant respiration. Ecological Applications 1: 157-167.

Sarkar, D., Mandal and M.C. Kundu. 2007. Increasing use efficiency of boron fertilizers by rescheduling the time and methods of application for crops in India. Plant and Soil 301: 77-85.

Selote, D.S., S. Bharti and R. Khanna-Chopra.2004. Drought acclimation reduces $\mathrm{O} 2$-accumulation and lipid peroxidation in wheat seedlings. Biochemical and Biophysical Research Communications 314:724-729.

Sillanpa, M.1982. Micronutrients at country level. An international study. FAO Soils Bulletin 63. Food and Agriculture Organization of United Nations. Rome Italy.

Tandon, H.L.S. 1995. Micronutrients in soils, crops and fertilizers. A sourcebook-cum- directory. Fertilizer Development and Consultation Organization. New Delhi. India.

Torun, A., L.G.A. Itekin, M. Kalayci, A. Yilmaz, S. Eker and L. Cakmak. 2001. Effects of zinc fertilization on grain yield and shoot concentrations of zinc, boron and phosphorus of 25 wheat cultivars grown on a zincdeficient and boron-toxic soil. Journal of Plant Nutrition 2:1817-1829.

Wilson, D.O., F.C. Boswell, K. Ohki, M.B. Parker, L.M. Shuman and M.D. Jellum. 1982. Change in soybean seed oil and protein as influenced by manganese nutrition. Crop Science 22: 948-952.

Zinselmeier, C., M.J. Lauer and J.S. Boyer. 1995. Reversing drought-induced losses in grain yield: Sucrose maintains embryo growth in maize. Crop Sciecne 35: 1390- 1400. 